\title{
Synthesis of the polyketide section of seragamide $A$ and related cyclodepsipeptides via Negishi cross coupling
}

\author{
Jan Hendrik Lang and Thomas Lindel ${ }^{*} \S$
}

\author{
Full Research Paper \\ Address: \\ TU Braunschweig, Institute of Organic Chemistry, Hagenring 30, \\ 38106 Braunschweig, Germany \\ Email: \\ Thomas Lindel* - th.lindel@tu-bs.de \\ * Corresponding author \\ § Fax: (+49) 531-391-7744, http://www.oc.tu-bs.de/lindel \\ Keywords: \\ jasplakinolide; marine natural products; Negishi coupling; polyketides; \\ stereoselective synthesis
}

\author{
Beilstein J. Org. Chem. 2019, 15, 577-583. \\ doi:10.3762/bjoc. 15.53 \\ Received: 01 November 2018 \\ Accepted: 12 February 2019 \\ Published: 28 February 2019 \\ Associate Editor: A. Kirschning \\ (ㄷ) 2019 Lang and Lindel; licensee Beilstein-Institut. \\ License and terms: see end of document.
}

\begin{abstract}
The synthesis of the polyketide section present in the potently cytotoxic marine cyclodepsipeptide jasplakinolide and related natural products, geodiamolides and seragamides, is reported. The key step is a Negishi cross coupling of ( $R$ )-(3-methoxy-2-methyl-3-oxopropyl)zinc(II) bromide and an (E)-iodoalkene that was synthesized via an aluminium ester enolate attack at $(R)$-propylene oxide. The overall synthesis comprises nine steps with an overall yield of $21 \%$. It proved to be possible to liberate the free 8 -hydroxynonenoic acid and to couple it with a protected tripeptide composed of L-alanine, $N, O$-dimethyl-D-iodotyrosine, and TIPS-protected L-threonine, which occurs as partial structure of seragamide A. The tripeptide section of seragamide A was assembled by solution-phase synthesis and an open-chain analogue of the natural product was obtained.
\end{abstract}

\section{Introduction}

Our program on the synthesis of biologically active natural products with peptide partial structures is driven by an interest in the chemistry of photoreactive amino acids and heterocycles that may find application in photoaffinity labelling. Knowing the binding of a natural product to a biological target at atomic resolution, as it is the case for the cyclodepsipeptide jasplakinolide A $(\mathbf{1}$, Scheme 1) [1,2], is an ideal situation for the validation of the chemoselectivity and efficiency of photoaffinity labelling. Recently, it has been determined by cryo-electron microscopy how jasplakinolide A (1) binds to F-actin and alters the actin skeleton in vivo, resulting in pronounced cytotoxicity [3]. A photoreactive derivative of the cytotoxic jasplakinolides, geodiamolides $[4,5]$, or seragamides (2-6, seragamides A-E) [6] could also enable the search for additional targets in the cell, including proteins involved in transport or even membrane components. For this purpose, the 2-bromoabrine unit of $\mathbf{1}$ could be replaced by phototryptophan [7], whereas photo $\beta$-phenylalanine [8] could replace the $\beta$-tyrosine moiety. For photoaffinity labelling studies with seragamides and geodiamolides, D-photophenylalanine could be incorporated. 


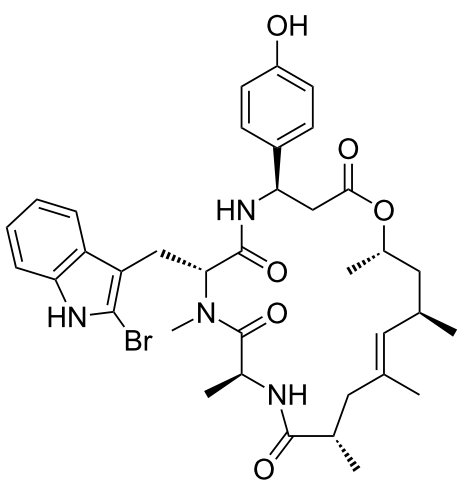

1: jasplakinolide A<smiles>[X]c1cc(C[C@H](NC(=O)[C@@H](Cc2ccc(O)c([X])c2)N(C)C(=O)[C@H](C)O)C(C)O)ccc1O</smiles>

2: seragamide $A(R=M e, X=I)$

3: seragamide $B(R=M e, X=B r)$

4: seragamide $C(R=M e, X=C l)$

5: seragamide $D(R=H, X=I)$

6: seragamide $\mathrm{E}\left(\mathrm{R}=\mathrm{CH}_{2} \mathrm{OH}, \mathrm{X}=\mathrm{I}\right)$<smiles>COC(=O)C(C)CBr</smiles>

8

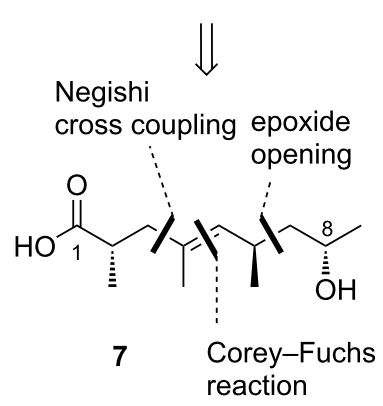

Scheme 1: Actin-binding cyclodepsipeptides, photo amino acids, retrosynthetic cuts of polyketide 7 leading to organozinc compound $\mathbf{8}$.

In this paper we describe, as the first step of such an endeavour, a new synthesis of the polyketide section present in seragamides and most of jasplakinolides and geodiamolides. We also include the synthesis of the protected tripeptide section of seragamide A (2), even if the macrocycle still remains to be assembled. Seragamide A (2) from the marine sponge Suberites japonicus (Thiele) has been synthesized only once, with relay ring-closing metathesis being the key step [9]. Characteristically, seragamides $\mathrm{A}-\mathrm{E}$ exhibit a L-threonine unit at the $\mathrm{C}$-terminus of the peptide moiety.

There is a considerable body of work on the synthesis of the $\mathrm{C}_{12}$ polyketide section. In most cases, the $\mathrm{C} 2-\mathrm{C} 3$ bond was formed by Ireland-, Johnson-, or Eschenmoser-Claisen rearrangement [10-17]. Alternatively, Evans methodology has been used [18-20]. The central C4-C5 double bond has also been constructed by Wittig reaction, cross metathesis, and ringclosing metathesis $[9,21,22]$. The $\mathrm{C} 3-\mathrm{C} 4$ bond has been assembled by 1,2-cuprate rearrangement [23]. Iterative construction of the polyketide from smaller building blocks has been achieved by Matteson homologation [24], that was also applied to the synthesis of the related polyketide section of lagunamide $A$ [25]. In addition, the shorter $\mathrm{C}_{11}$ polyketide section of the closely related chondramides has been assembled in several ways [26-29].

\section{Results and Discussion}

In our approach the polyketide section (7, Scheme 1) of seragamide A (2) was to be assembled via construction of the C3-C4 bond by $\mathrm{sp}^{3}-\mathrm{sp}^{2}$ Negishi cross coupling. The required organozinc reagent $\mathbf{8}$ has been applied occasionally and is accessible from the corresponding commercially available chiral bromide [30-34]. The coupling partner would be an $(E)-$ iodoalkene that was to be constructed from enantiomerically pure $(R)$-propylene oxide. The $\mathrm{C} 4-\mathrm{C} 5$ double bond would be formed by Corey-Fuchs reaction. Reaction of the aluminium enolate of tert-butyl propionate $(\mathbf{9}$, Scheme 2$)$ with $(S)$-propylene oxide had provided Taylor et al. with a mixture of diastereomers of $\alpha$-methylated $\gamma$-hydroxyester 11 favouring the $(2 S, 4 S)$-syn over the $(2 R, 4 S)$-anti isomer $[35,36]$. As the configuration at $\mathrm{C} 4$ was expected to be invertible in a later step, we aimed for the $(2 R, 4 R)$ configuration by choosing $(R)$-propylene oxide as electrophile. We obtained an acceptable ratio of diastereomers of 11 ( $84: 16$ in favour of $(2 R, 4 R), 62 \%$ combined) after having treated tert-butyl propionate (9) with $\mathrm{LDA} / \mathrm{Et}_{2} \mathrm{AlCl}$ (Scheme 2). Performing the reaction at $-78^{\circ} \mathrm{C}$ instead of $-40{ }^{\circ} \mathrm{C}$ unexpectedly diminished the $\mathrm{dr}$, which is in agreement with results by Liu, Petersen and co-workers [37]. The analogous reaction of adamantyl ester $\mathbf{1 0}$ (obtained from adamantan1-ol and propionyl chloride/pyridine, $85 \%$ ) instead of 9 gave a quantitative yield of the hydroxy ester 12, but a lower $\mathrm{dr}$ (4:1). 


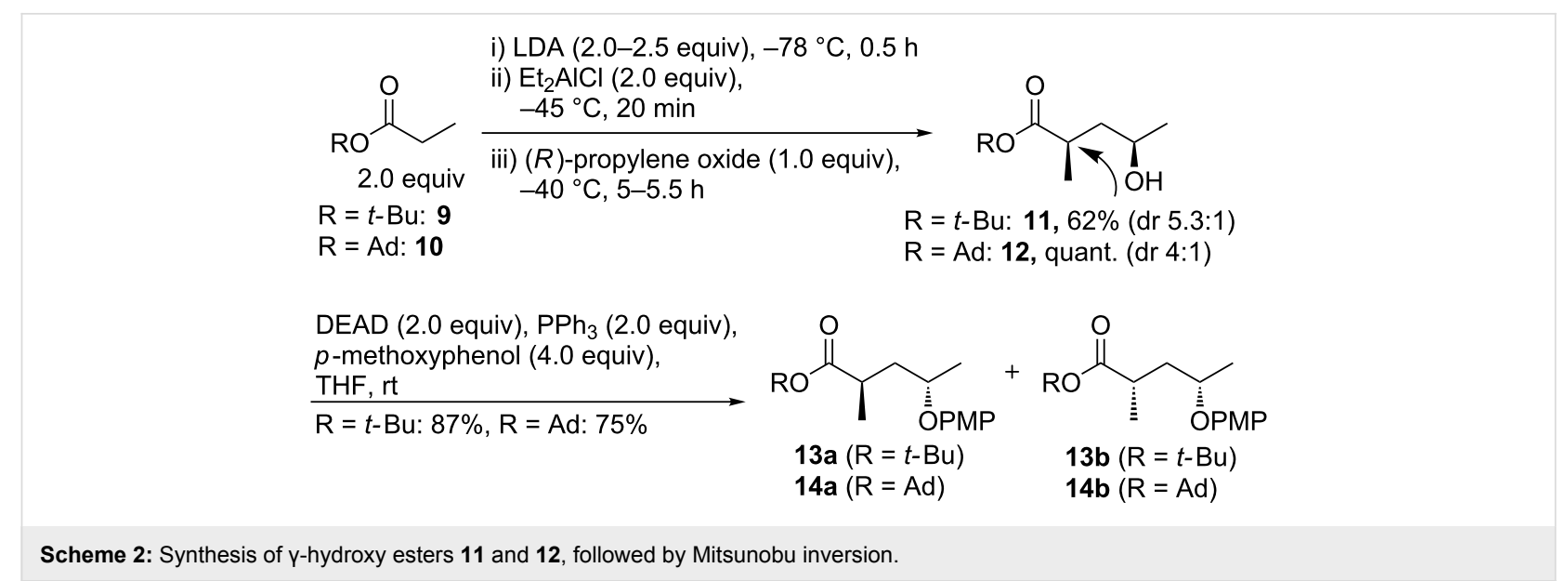

For both cases, we inverted the carbinol centre by Mitsunobu reaction employing $p$-methoxyphenol. DEAD was used instead of DIAD because of facilitated purification. It was possible to separate the diastereomers of product $\mathbf{1 3}$ by column chromatography. The use of DMEAD (di-2-methoxyethyl azodicarboxylate) [38] was inferior (33\%). The PMP protecting group was envisioned to be stable during the following steps and to be selectively cleavable with ceric ammonium nitrate (CAN).

Reduction of tert-butyl ester 13a to the alcohol by portionwise addition of DIBAL and careful temperature control (slow warm-up from -78 to $-30{ }^{\circ} \mathrm{C}$ ) afforded the alcohol without $\alpha$-epimerization, which was oxidized to aldehyde 15 (IBX, Scheme 3). Adamantyl ester 14 resisted reduction under the same conditions and was abandoned.

Dibromoalkene $\mathbf{1 6}$ was accessed from aldehyde $\mathbf{1 5}$ under Corey-Fuchs conditions and treated with $n$-hexane to separate triphenylphosphane oxide. For the conversion of $\mathbf{1 6}$ to the internal alkyne 17, the use of a large excess of freshly prepared LDA and iodomethane with a slow warm-up from $-78{ }^{\circ} \mathrm{C}$ to $\mathrm{rt}$ [39] proved to be superior to the more commonly employed $n$-BuLi/MeI reagent combination that led to the formation of a series of side products. We also attempted a Bestmann-Ohira reaction with in situ formation of the diazo phosphonate [40] that gave a slightly inferior yield after methylation of the alkyne terminus. Hydrozirconation/iodination of alkyne 17 required freshly prepared Schwartz reagent (3 equiv) and iodine (3 equiv) to obtain yields of $(E)$-olefin 18 above $80 \%$ with perfect stereo- and regioselectivity. For comparison, as part of a study towards kendomycin, Arimoto and co-workers had published a route to a 1:1 mixture of diastereomers of a TBSprotected analogue of building block 18 [41].

Negishi cross coupling of $\mathrm{sp}^{3}$ organozinc homoenolate $\mathbf{8}$ (2.75 equiv) and iodoalkene $18\left(10 \mathrm{~mol} \%\left[\mathrm{Pd}(\mathrm{dppf}) \mathrm{Cl}_{2} \times\right.\right.$
DCM] in DCM) afforded a satisfying $75 \%$ yield of the protected nonenoic acid $\mathbf{2 0}$ (Scheme 3 ). For the synthesis of organozinc homoenolate $\mathbf{8}$, the $\mathrm{MnBr}_{2} / \mathrm{CuCl}$-catalyzed reaction of diethylzinc with $\beta$-bromopropionic acid ester 19 in DMPU proved to be the best choice [42]. Racemization was avoided.

The PMP protecting group was removed (CAN) affording methyl ester 7 ( $82 \%$, Scheme 3). For comparison with literature data we converted 7 to the free carboxylic acid carrying a TBSprotected hydroxy group at C8 by silylation with TBSOTf/2,6lutidine, followed by saponification with $\mathrm{LiOH}$.

To investigate whether polyketide 7 could be coupled in an unprotected form with the peptide fragment of seragamide A (2), we synthesized the tripeptide section. The assembly of the iodotyrosine moiety commenced with D-3-iodotyrosine that was obtained in $63 \%$ yield from D-tyrosine upon treatment with iodine (1 equiv, added via syringe pump over $90 \mathrm{~min}$ to avoid diiodination) in aqueous ammonia [43] (Scheme 4). This setup also served to avoid the formation of excess amounts of the explosive iodinating reagent $\mathrm{NI}_{3}$. On work-up, the $\mathrm{pH}$ had to be adjusted to exactly 4.5 to destroy remaining $\mathrm{NI}_{3}$ and to precipitate the product. Other iodination conditions such as use of $\mathrm{NaI} /$ $\mathrm{NaOCl}[44,45]$ or $\mathrm{I}_{2} / \mathrm{CAN}[46]$ did not convince. Boc protection yielded $N$-Boc-D-3-iodotyrosine (21), which underwent three-fold methylation to $N$-methyl- $O$-methyliodotyrosine methyl ester 22 (82\% yield, er 4:1, CHIRALPAK ${ }^{\circledR}$ IA, hexane/ iPrOH 9:1). Partial racemization of 21 could not be suppressed since a slight excess of base was always necessary, whereas the use of exactly stoichiometric amounts resulted in incomplete $N$-methylation. Treating the Boc-protected methyl ester of iodotyrosine 21 with a larger excess of base and methyl iodide (10 equiv each) led to the formation of the $\alpha$-quaternary amino acid 23 (Scheme 4). An alternative route to the $N$-methylated product via oxazolidinone $\mathbf{2 4}$ was hampered by low yield on reaction with paraformaldehyde $[47,48]$. Although subsequent 


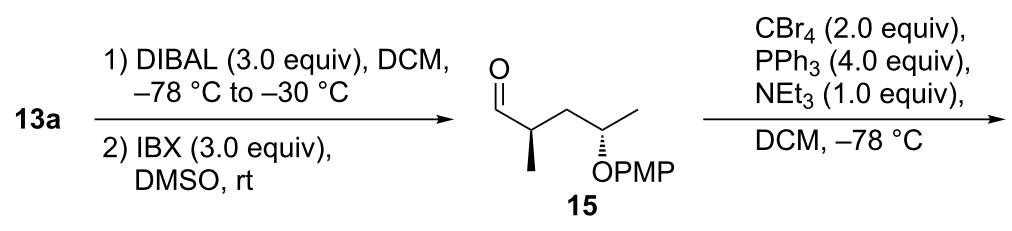

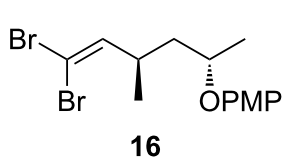

$81 \%$ (3 steps from 13a) i) LDA ( 10 equiv), $-78^{\circ} \mathrm{C}$

ii) Mel (20 equiv), THF, $-78{ }^{\circ} \mathrm{C}$ to rt $91 \%$

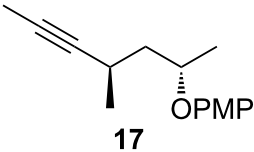

17
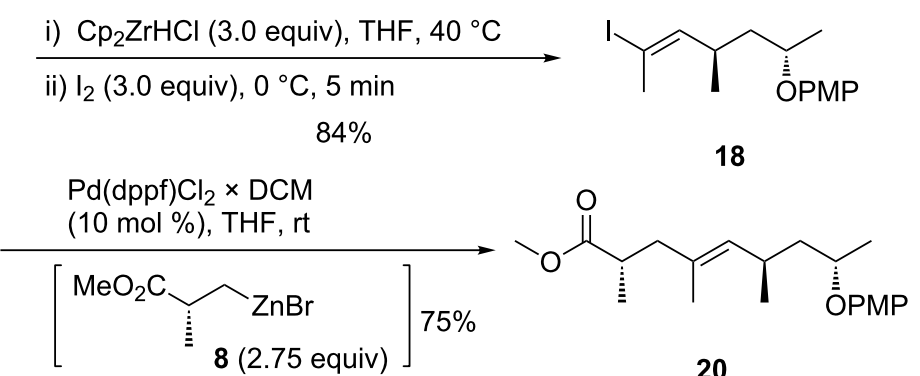

20

$\mathrm{MnBr}_{2}(5 \mathrm{~mol} \%), \mathrm{CuCl}(4 \mathrm{~mol} \%)$, $\mathrm{Et}_{2} \mathrm{Zn}$ (0.92 equiv), DMPU, rt, $4 \mathrm{~h}$

CAN (2.2 equiv),

$82 \% \mathrm{MeCN} / \mathrm{H}_{2} \mathrm{O}(4: 1)$, $0{ }^{\circ} \mathrm{C}, 5 \mathrm{~min}$<smiles>COC(=O)[C@H](C)CBr</smiles>

19<smiles>COC(=O)[C@H](C)C/C(C)=C/[C@H](C)C[C@H](C)O</smiles>

Scheme 3: Synthesis of the polyketide section 7.<smiles>CN(C(=O)OC(C)(C)C)[C@H](Cc1ccc(O)c(I)c1)C(=O)O</smiles>

$25,93 \%$

i) $\mathrm{TFA}, \mathrm{Et}_{3} \mathrm{SiH}$ (4.0 equiv), DCM, rt

ii) $\mathrm{Boc}_{2} \mathrm{O}$ ( 1.5 equiv), $\mathrm{HO}$ $1 \mathrm{~N}$ aq. $\mathrm{NaOH}$ (2.0 equiv), $\mathrm{THF} / \mathrm{H}_{2} \mathrm{O}$, rt

24, $39 \%$

$\uparrow(\mathrm{HCHO})_{n}(5.0$ equiv), cat. PTSA. $\mathrm{H}_{2} \mathrm{O}$, $\mathrm{PhMe} / \mathrm{DMF}$, reflux

1) $1 \mathrm{~N}$ aq. $\mathrm{I}_{2}$ (1.0 equiv), $\mathrm{NH}_{3}(25 \%$ aq. $)$,

D-tyrosine

2) $\mathrm{Boc}_{2} \mathrm{O}, \mathrm{NEt}_{3}$, dioxane $/ \mathrm{H}_{2} \mathrm{O}$, rt $61 \%$ (2 steps)<smiles>COC(=O)[C@](C)(Cc1ccc(OC)c(I)c1)N(C)C(=O)OC(C)(C)C</smiles>

23<smiles>CCCN[C@@H](Cc1ccc(O)c(I)c1)C(=O)O</smiles>

21

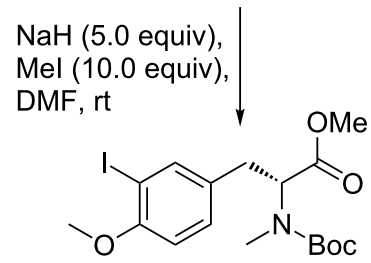

22, $82 \%$ (er $4: 1$ ) 
reduction of 24 with $\mathrm{Et}_{3} \mathrm{SiH} / \mathrm{TFA}$ and reprotection of the free $\mathrm{N}$-methyl amino acid with $\mathrm{Boc}_{2} \mathrm{O}$ proceeded smoothly and delivered iodotyrosine $\mathbf{2 5}$, the overall yield via $\mathbf{2 4}$ was not satisfying.

After Boc removal at 22, HATU/HOAt-mediated coupling with Boc-protected L-alanine afforded dipeptide 26, which was saponified and coupled with TIPS-protected threonine methyl ester (obtained with TIPSCl/DBU/MeCN) to provide tripeptide 27 (Scheme 5). Peptides 26 and 27 were obtained in nearly quantitative yield, albeit as mixtures of inseparable diastereomers (4:1), as consequence of the optical impurity of $\mathbf{2 2}$. Only when following the coupling order shown in Scheme 5, high yields could be obtained.

The labile carboxylic acid $\mathbf{2 9}$ was formed by saponification of methyl ester 7 ( $\mathrm{LiOH}, \mathrm{H}_{2} \mathrm{O} / \mathrm{MeOH}$ ) and underwent BEP-mediated coupling with tripeptide 27 (Scheme 5). Product 31 (60\%) was obtained with a higher dr of 9:1 than tripeptide 27 (dr 4:1). We have evidence that the major side product of $\mathbf{3 1}$ was a desilylated analogue, for which the ${ }^{1} \mathrm{H}$ NMR spectrum indicated a lower dr of about 7:3. The analogous product $\mathbf{3 0}$ carrying an 8-OPMP group was obtained from PMP-protected polyketide 28.

The endgame of a total synthesis of seragamide A (2) will have to address the macrocyclisation, desilylation of the threonine moiety, and $O$-demethylation of the D-iodotyrosine unit of $\mathbf{3 1}$. In orienting reactions on small scale, desilylation of $\mathbf{3 1}$ (TBAF) was a spot-to-spot conversion. Saponification of both the silylated and desilylated methyl esters with $\mathrm{LiOH}$ was possible, as long as very mild acidic conditions were applied on work-up. However, macrocyclisation of the TIPS-protected or the desilylated acid did not occur. Under Yamaguchi conditions, we observed complete decomposition in both cases. Shiina conditions gave a complex product mixture, if the TIPS group was present, whereas the desilylated acid provided a product that apparently had undergone dehydration, as judged by TLC-MS coupling. In course of their recent synthesis of plusbacin $\mathrm{A}_{3}$, Ichikawa et al. experienced similar difficulties when attempting esterification of a bulky $\beta$-OTIPS-substituted amino acid with a secondary alcohol under a variety of conditions [49].

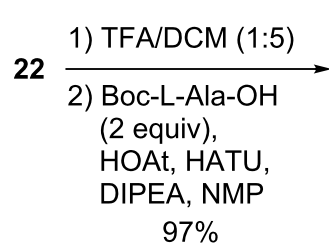

$97 \%$<smiles>COC(=O)NC(C)C(=O)N(C)[C@@H](Cc1ccc(OC)c(I)c1)C(=O)NC(C)(C)C</smiles>

$26(\mathrm{dr} 4: 1)$

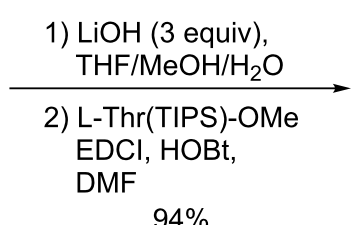

$94 \%$

i) TFA/DCM, $0{ }^{\circ} \mathrm{C}, 4 \mathrm{~h}$<smiles>COC(=O)NC(C)C(=O)N(C)[C@@H](Cc1ccc(OC)c(I)c1)C(=O)N[C@H](C(=O)OC)[C@H](C)OC(C)(C)C</smiles>

ii)<smiles>[R20]C(C)CC(C)/C=C(\C)C[C@H](C)C(=O)O</smiles>

28: $R=P M P($ from 20)

29: $\mathrm{R}=\mathrm{H}$ (from 7)

BEP, DIPEA

$\mathrm{DCM}, 0^{\circ} \mathrm{C}$

$27(\mathrm{dr} 4: 1)$

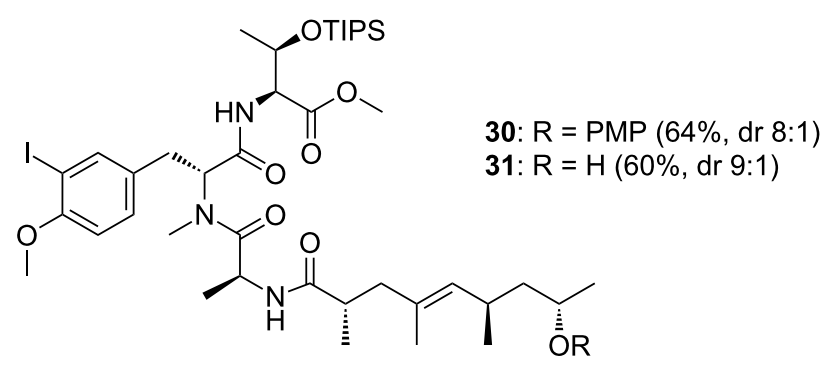

Scheme 5: Synthesis of the doubly protected open chain peptide-polyketide 31. 


\section{Conclusion}

We developed a short synthesis of the polyketide building block present in most of the jasplakinolides, geodiamolides, and seragamides, potently cytotoxic peptide-polyketide cyclodepsipeptides stabilizing filamentous actin. The key step is a Negishi cross coupling, and the carbon atoms stem from $(R)$-propylene oxide (C7-C9), tert-butyl propionate $(9, \mathrm{C} 5-\mathrm{C} 6$, 6-Me), $\mathrm{CBr}_{4}(\mathrm{C} 4), \mathrm{MeI}(4-\mathrm{Me})$, and $(R)$-(3-methoxy-2-methyl3-oxopropyl)zinc(II) bromide (8, C1-C3, 2-Me). We obtained 8 -hydroxyester 7 within nine steps and an overall yield of $21 \%$ starting from $(R)$-propylene oxide. The efficiency of our route to polyketide 7 compares well to earlier approaches. It proved to be possible to liberate the free carboxylic acid $\mathbf{2 9}$ and to couple it with the protected tripeptide 27 that was obtained by solution phase synthesis. We will now aim at the macrocyclisation of analogues of compound 31, which will probably require replacement of the bulky TIPS group installed at the threonine unit. The synthesis of photoreactive tripeptide analogues incorporating photo amino acids 4-6 will be explored thereafter.

\section{Supporting Information}

\section{Supporting Information File 1}

Experimental procedures and NMR spectra.

[https://www.beilstein-journals.org/bjoc/content/ supplementary/1860-5397-15-53-S1.pdf]

\section{Acknowledgements}

J. H. L. thanks the Fonds der Chemischen Industrie for a doctoral stipend. Gesa Hertrampf and Jana Kielhorn are thanked for experimental assistance.

\section{ORCID ${ }^{\circledR}$ iDs}

Thomas Lindel - https://orcid.org/0000-0002-7551-5266

\section{References}

1. Crews, P.; Manes, L. V.; Boehler, M. Tetrahedron Lett. 1986, 27 , 2797-2800. doi:10.1016/s0040-4039(00)84645-6

2. Zabriskie, T. M.; Klocke, J. A.; Ireland, C. M.; Marcus, A. H.; Molinski, T. F.; Faulkner, D. J.; Xu, C.; Clardy, J. C. J. Am. Chem. Soc. 1986, 108, 3123-3124. doi:10.1021/ja00271a062

3. Pospich, S.; Kumpula, E.-P.; von der Ecken, J.; Vahokoski, J.; Kursula, I.; Raunser, S. Proc. Natl. Acad. Sci. U. S. A. 2017, 114, 10636-10641. doi:10.1073/pnas.1707506114

4. Chan, W. R.; Tinto, W. F.; Manchand, P. S.; Todaro, L. J. J. Org. Chem. 1987, 52, 3091-3093. doi:10.1021/jo00390a023

5. Coleman, J. E.; Van Soest, R.; Andersen, R. J. J. Nat. Prod. 1999, 62, 1137-1141. doi:10.1021/np990155o And references cited therein.

6. Tanaka, C.; Tanaka, J.; Bolland, R. F.; Marriott, G.; Higa, T. Tetrahedron 2006, 62, 3536-3542. doi:10.1016/j.tet.2006.01.099
7. Wartmann, T.; Lindel, T. Eur. J. Org. Chem. 2013, 1649-1652. doi:10.1002/ejoc.201201726

8. Schäckermann, J.-N.; Lindel, T. Z. Naturforsch., B: J. Chem. Sci. 2014, 69, 1088-1096. doi:10.5560/znb.2014-4152

9. Arndt, H.-D.; Rizzo, S.; Nöcker, C.; Wakchaure, V. N.; Milroy, L.-G.; Bieker, V.; Calderon, A.; Tran, T. T. N.; Brand, S.; Dehmelt, L.; Waldmann, H. Chem. - Eur. J. 2015, 21, 5311-5316. doi:10.1002/chem.201500368

10. Rao, A. V. R.; Gurjar, M. K.; Nallaganchu, B. R.; Bhandari, A. Tetrahedron Lett. 1993, 34, 7085-7088. doi:10.1016/s0040-4039(00)61605-2

11. Grieco, P. A.; Hon, Y. S.; Perez-Medrano, A. J. Am. Chem. Soc. 1988, 110, 1630-1631. doi:10.1021/ja00213a050

12. Chu, K. S.; Negrete, G. R.; Konopelski, J. P. J. Org. Chem. 1991, 56, 5196-5202. doi:10.1021/jo00017a037

13. Ghosh, A. K.; Moon, D. K. Org. Lett. 2007, 9, 2425-2427. doi:10.1021/ol070855h

14. Hirai, Y.; Yokota, K.; Sakai, H.; Yamazaki, T.; Momose, T. Heterocycles 1989, 29, 1865-1869. doi:10.3987/com-89-5123

15. White, J. D.; Amedio, J. C., Jr. J. Org. Chem. 1989, 54, 736-738. doi:10.1021/jo00265a003

16. Schmidt, U.; Siegel, W.; Mundinger, K. Tetrahedron Lett. 1988, 29 , 1269-1270. doi:10.1016/s0040-4039(00)80273-7

17. Rao, A. V. R.; Gurjar, M. K.; Nallaganchu, B. R.; Bhandari, A. Tetrahedron Lett. 1993, 34, 7081-7084. doi:10.1016/s0040-4039(00)61604-0

18. Imaeda, T.; Hamada, Y.; Shioiri, T. Tetrahedron Lett. 1994, 35 , 591-594. doi:10.1016/s0040-4039(00)75846-1

19. Kang, S.-K.; Lee, D.-H. Synlett 1991, 175-176. doi:10.1055/s-1991-20668

20. Wattanasereekul, S.; Maier, M. E. Adv. Synth. Catal. 2004, 346, 855-861. doi:10.1002/adsc.200404004

21. Tannert, R.; Hu, T.-S.; Arndt, H.-D.; Waldmann, H. Chem. Commun. 2009, 1493-1495. doi:10.1039/b900342h

22. Tannert, R.; Milroy, L.-G.; Ellinger, B.; Hu, T.-S.; Arndt, H.-D.; Waldmann, H. J. Am. Chem. Soc. 2010, 132, 3063-3077. doi:10.1021/ja9095126

23. Ashworth, P.; Broadbelt, B.; Jankowski, P.; Kocienski, P.; Pimm, A.; Bell, R. Synthesis 1995, 199-206. doi:10.1055/s-1995-3870

24. Unsworth, P. J.; Leonori, D.; Aggarwal, V. K. Angew. Chem., Int. Ed. 2014, 53, 9846-9850. doi:10.1002/anie.201405700

25. Gorges, J.; Kazmaier, U. Org. Lett. 2018, 20, 2033-2036. doi:10.1021/acs.orglett.8b00576

26. Eggert, U.; Diestel, R.; Sasse, F.; Jansen, R.; Kunze, B.; Kalesse, M. Angew. Chem., Int. Ed. 2008, 47, 6478-6482. doi:10.1002/anie.200801156

27. Waldmann, H.; Hu, T.-S.; Renner, S.; Menninger, S.; Tannert, R.; Oda, T.; Arndt, H.-D. Angew. Chem., Int. Ed. 2008, 47, 6473-6477. doi:10.1002/anie.200801010

28. Schmauder, A.; Sibley, L. D.; Maier, M. E. Chem. - Eur. J. 2010, 16, 4328-4336. doi:10.1002/chem.200903500

29. Becker, D.; Kazmaier, U. Eur. J. Org. Chem. 2015, 4198-4213. doi:10.1002/ejoc.201500369

30. Petri, A. F.; Schneekloth, J. S.; Mandal, A. K.; Crews, C. M. Org. Lett. 2007, 9, 3001-3004. doi:10.1021/ol071024e

31. Cui, C.; Dai, W.-M. Org. Lett. 2018, 20, 3358-3361. doi:10.1021/acs.orglett.8b01269

32. Dimopoulos, P.; Athlan, A.; Manaviazar, S.; Hale, K. J. Org. Lett. 2005, 7, 5373-5376. doi:10.1021/ol051935t 
33. Francavilla, C.; Chen, W.; Kinder, F. R., Jr. Org. Lett. 2003, 5, 1233-1236. doi:10.1021/ol034186t

34. Corrêa, I. R.; Pilli, R. A. Angew. Chem., Int. Ed. 2003, 42, 3017-3020. doi:10.1002/anie.200351347

35. Sturm, T.-J.; Marolewski, A. E.; Rezenka, D. S.; Taylor, S. K. J. Org. Chem. 1989, 54, 2039-2040. doi:10.1021/jo00270a007

36. Taylor, S. K.; Fried, J. A.; Grassl, Y. N.; Marolewski, A. E.; Pelton, E. A.; Poel, T.-J.; Rezanka, D. S.; Whittaker, M. R. J. Org. Chem. 1993, 58, 7304-7307. doi:10.1021/jo00077a069

37. Qabaja, G.; Benavides, A. R.; Liu, S.; Petersen, K. S. J. Org. Chem. 2015, 80, 133-140. doi:10.1021/jo5022019

38. Hagiya, K.; Muramoto, N.; Misaki, T.; Sugimura, T. Tetrahedron 2009, 65, 6109-6114. doi:10.1016/j.tet.2009.05.048

39. Handa, M.; Scheidt, K. A.; Bossart, M.; Zheng, N.; Roush, W. R. J. Org. Chem. 2008, 73, 1031-1035. doi:10.1021/jo702250z

40. Roth, G. J.; Liepold, B.; Müller, S. G.; Bestmann, H. J. Synthesis 2004, 59-62. doi:10.1055/s-2003-44346

41. Sengoku, T.; Uemura, D.; Arimoto, H. Chem. Lett. 2007, 36, 726-727. doi:10.1246/cl.2007.726

42. Klement, I.; Knochel, P.; Chau, K.; Cahiez, G. Tetrahedron Lett. 1994, 35, 1177-1180. doi:10.1016/0040-4039(94)88017-4

43. Pitt-Rivers, R. Chem. Ind. 1956, 21.

44. Edgar, K. J.; Falling, S. N. J. Org. Chem. 1990, 55, 5287-5291. doi:10.1021/jo00305a026

45. Schmidt, E. W.; Nelson, J. T.; Fillmore, J. P. Tetrahedron Lett. 2004, 45, 3921-3924. doi:10.1016/j.tetlet.2004.03.112

46. Das, B.; Krishnaiah, M.; Venkateswarlu, K.; Reddy, V. S. Tetrahedron Lett. 2007, 48, 81-83. doi:10.1016/j.tetlet.2006.11.009

47. Hitotsuyanagi, Y.; Miyazawa, A.; Hinosawa, T.-a.; Nakagawa, Y.; Hasuda, T.; Takeya, K. Bioorg. Med. Chem. Lett. 2013, 23, 6728-6731. doi:10.1016/j.bmcl.2013.10.033

48. Moschitto, M. J.; Lewis, C. A. Eur. J. Org. Chem. 2016, 4773-4777 doi:10.1002/ejoc.201600741

49. Katsuyama, A.; Yakushiji, F.; Ichikawa, S. J. Org. Chem. 2018, 83, 7085-7101. doi:10.1021/acs.joc.8b00038

\section{License and Terms}

This is an Open Access article under the terms of the Creative Commons Attribution License (http://creativecommons.org/licenses/by/4.0). Please note that the reuse, redistribution and reproduction in particular requires that the authors and source are credited.

The license is subject to the Beilstein Journal of Organic Chemistry terms and conditions: (https://www.beilstein-journals.org/bjoc)

The definitive version of this article is the electronic one which can be found at: $\underline{\text { doi: } 10.3762 / \text { bjoc. } 15.53}$ 